\title{
A precautionary note on shear bands as kinematic indicators
}

\author{
J. H. Behrmann \\ Institut für Geowissenschaften und Lithosphärenforschung, Universität Giessen, D-6300 Giessen, \\ West Germany
}

(Received 23 May 1986; accepted in revised form 25 February 1987)

\begin{abstract}
The orientation of shear bands relative to foliations defined by elongated mineral aggregates, is often used to determine the large-scale sense of displacement in ductile faults. Data from contact strain zones at the bases of large overthrust complexes in the Eastern Alps and the Betic Cordilleras demonstrate that there is not always a simple geometrical relation between shear band orientation and sense of vorticity in bulk non-coaxial flow. In addition to single shear band sets that show displacements synthetic with the large-scale displacement, there are single sets with antithetic displacements, and conjugate sets. The last two observations are at variance with published data and interpretations, and cast doubts on the general applicability of shear bands as indicators of large scale flow kinematics.
\end{abstract}

\section{INTRODUCTION}

SINGLE SETS of small-scale shear zones at low angles to a previous planar anisotropy are often observed in connection with large-scale ductile shearing in the earth's crust. They are termed shear bands (White 1979) or extensional crenulation cleavages (ecc for short) (Platt 1979), and the sense of displacement along them has repeatedly been used as indicator of the large-scale sense of movement in sheared rocks (e.g. Berthé et al. 1979, Ponce de Leon \& Choukroune 1980, Simpson \& Schmid 1983, Weijermars \& Rondeel 1984, Lister \& Snoke 1984, Davis et al. 1986). It should be clarified at this point that in the first two examples (Berthé et al. 1979, Ponce de Leon \& Choukroune 1980) the features described are mesoscopic zones of high shear strains ( $C$-bands) that are demonstrably parallel to the boundaries of regional scale simple shear zones. In the other studies referred to above this geometrical relationship is not so clear, and leaves open questions concerning the exact shear zone geometries and kinematics (e.g. heterogeneous simple shear or not). Conjugate ecc sets have been interpreted as indicators of coaxial deformation histories (Platt \& Vissers 1980). However, recent experiments (Harris \& Cobbold 1985) and theoretical considerations (Platt 1984) have pointed out that conjugate sets of small-scale shears can develop in bulk simple shearing of anisotropic materials, making a clear-cut kinematic interpretation of field structures difficult.

In this note I report data from two crustal-scale movement zones (Figs. 1 and 5) to show that conjugate sets, and single sets of shear bands with displacements antithetic to the regional sense of movement can occur in situations where it is geologically reasonable to assume overall non-coaxial deformation histories with a regionally consistent sense of vorticity. This assumption is tested in both cases by the asymmetry of quartz $c$-axis fabrics as kinematics indicators.

\section{THE BETIC MOVEMENT ZONE (BMZ)}

The BMZ (Fig. 1) is a broad zone of high ductile strain separating the Nevado-Filabride and Higher Betic nappe complexes in the Betic Zone. The Betic Zone is the internal, metamorphic segment of the Betic orogen of Alpine age in southern Spain. Structural (Platt 1982) and petrofabric evidence (Behrmann \& Platt 1982) suggest a N-NE-directed emplacement of the Higher Betic nappes over the Nevado-Filabride basement. The associated structures are most thoroughly studied in the Sierra Alhamilla, and Platt \& Behrmann (1986) described the BMZ as a locus of $\mathrm{km}$-scale partitioning of near-coaxial and non-coaxial deformation. Non-coaxial flow is concentrated in two ultramylonite belts, (the Fuentes and Cuillas mylonites), and deformation with a lesser degree of non-coaxiality or even local coaxial flow prevails in the synchronously tectonized wall rocks. The extensional crenulation cleavages are ductile features (Behrmann 1984a), and their syn-mylonitic origin is

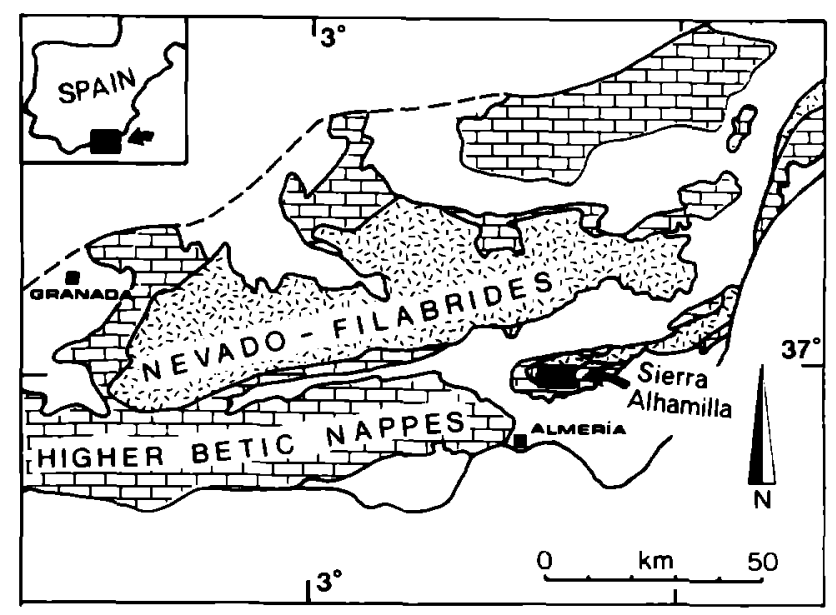

Fig. 1. Tectonic sketch map of the eastern Betic Zone (after Platt 1982). The black rectangle indicates the study area. 
extensively discussed elsewhere (Platt \& Behrmann 1986, pp. 26-27), but the main arguments are as follows. (1) Eccs are restricted to mica-rich lithologies. Where interlayered with quartz-rich rocks, the latter lack eccs and show homogeneous main-phase deformation (see also Fig. 2). (2) Shearing along the eccs causes extension in the plane of the foliation. (3) Intensity of ecc development and the main-phase strain magnitude can be spatially correlated. (4) Mylonitic foliation and eccs are overprinted by the next distinguishable set of folds. (5) The syntectonic mineral assemblages within the eccs and in specimens without them are identical and reflect lowermost greenschist facies conditions during mainphase shearing.

Figure 3 shows the orientation of conjugate extensional crenulation cleavage sets with respect to the mylonitic foliations and stretching lineations in a micarich variety of the Cuillas mylonite at [UTM 556950/ 4092100] on the Almeria 1:50,000 topographic sheet. In connection with extensional crenulation cleavages, 'foliation' denotes the enveloping surface of the warped foliation in this diagram and throughout this paper (see Platt \& Vissers 1980 for explanation). Ecc 1 is inclined at $30^{\circ}$ to the foliation and has displacements synthetic to the bulk sense of shear. $E c c 2$ is inclined at $60^{\circ}$ to the foliation and has displacements antithetic to the bulk sense of shear. The most remarkable feature is that each set has its own intersection lineation with the main mylonitic foliation, and that the intersection lineations make angles of less than $90^{\circ}$ to the stretching lineation, imprinting a phacoid-type pattern onto the mylonitic foliation planes. The steep SE-dip of the mylonitic foliation in Fig. 3 is explained by the fact that the Cuillas mylonite is backsteepened in the outcrop where the data were collected (see fig. 8, section $\mathrm{C}-\mathrm{C}^{\prime}$, and fig. 9, section E-E' in Platt \& Behrmann 1986). This is an effect of local refolding, and clearly postdates the generation of the mylonitic fabrics.
Figure 4(a) shows the orientations of ecc planes relative to the mylonitic foliation and the stretching lineation in the tectonized wall rocks of the Fuentes and Cuillas mylonites. It is a collection of data from the whole of the Sierra Alhamilla, but represents the geometrical relation between $L, S$ and $e c c$ on a hand specimen scale. The deviation from orientations on the outer circle of the equal-area plot presents a problem, as it indicates that the ecc planes do not necessarily propagate in the direction of overthrusting as depicted by the stretching lineation. An interpretation as a regional flattening-type fabric is ruled out by the fact that regional plane-strain deformation in the BMZ is well documented (Behrmann 1984b). It implies that the displacement on ecc planes may not be necessarily at right angles to their intersection with the foliation. This presents some interesting insights into the mechanics of ecc formation. The orientation of a nucleating ecc and its propagation direction may be prescribed by intrinsic local anisotropies within the mylonite layers (Fig, 2), such as undeformable porphyroclasts, or pinch-and-swell features of the mylonitic foliation. A similar interpretation of sigmoidal shear bands oblique to the local stretching direction has been given by Burg \& Harris (1982), who compared them with Lüders bands. Such a comparison means that the eccs in Figs. 2-4 owe their orientations to local mechanical constraints rather than bulk kinematic ones. Additional evidence comes from the single set with displacements antithetic to the bulk sense of vorticity in Fig. 2. Some of the eccs show ramp-flat geometries akin to those commonly observed in thrust tectonics. Extensional flats are confined to mechanically incompetent mica-rich lithologies. A purely kinematic interpretation in terms of classical slip-line theory (Hill 1950) seems inappropriate in view of the fact that it ignores the anisotropy effects that control shear band generation and reorientation.
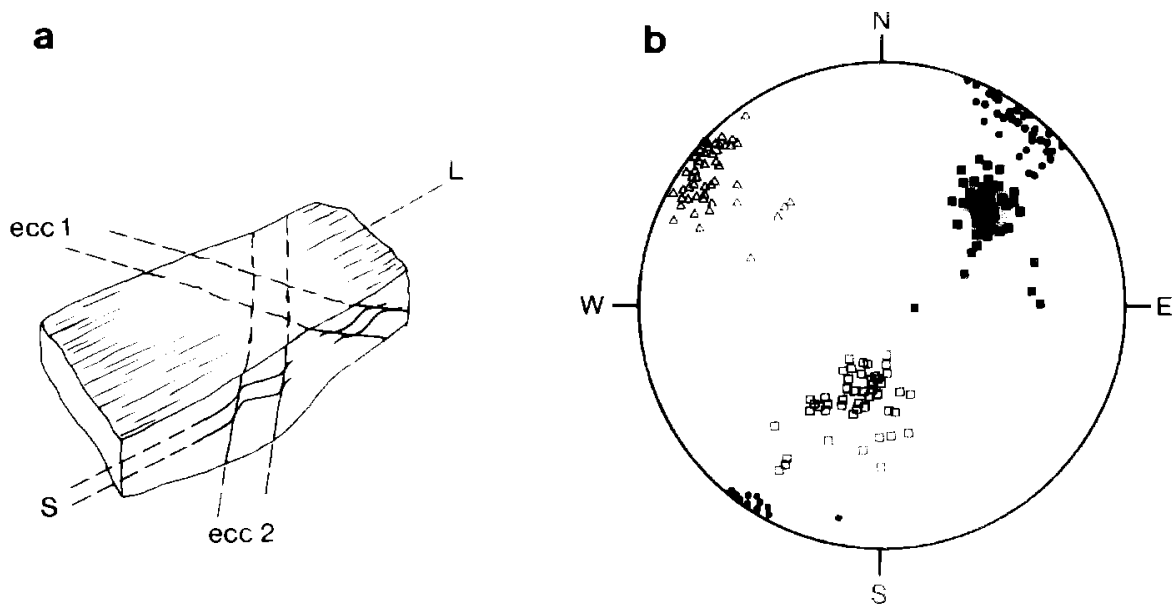

Fig. 3. Orientation of conjugate sets of extensional crenulation cleavages in the Cuillas mylonite of the Sierra Alhamilla. (a) Geometrical relationship between mesoscopic $L-S$ fabric and intersection lineations produced by ecc1 and ecc2. (b) Lower hemisphere, equal-area plot of the individual data. Solid circles, stretching lineation $(L)$; solid quadrangles and open quadrangles, intersection lineations of the mylonitic foliation $(S)$ with ecc1 and ecc2. Open triangles, poles to the mylonitic foliation $(S)$. 

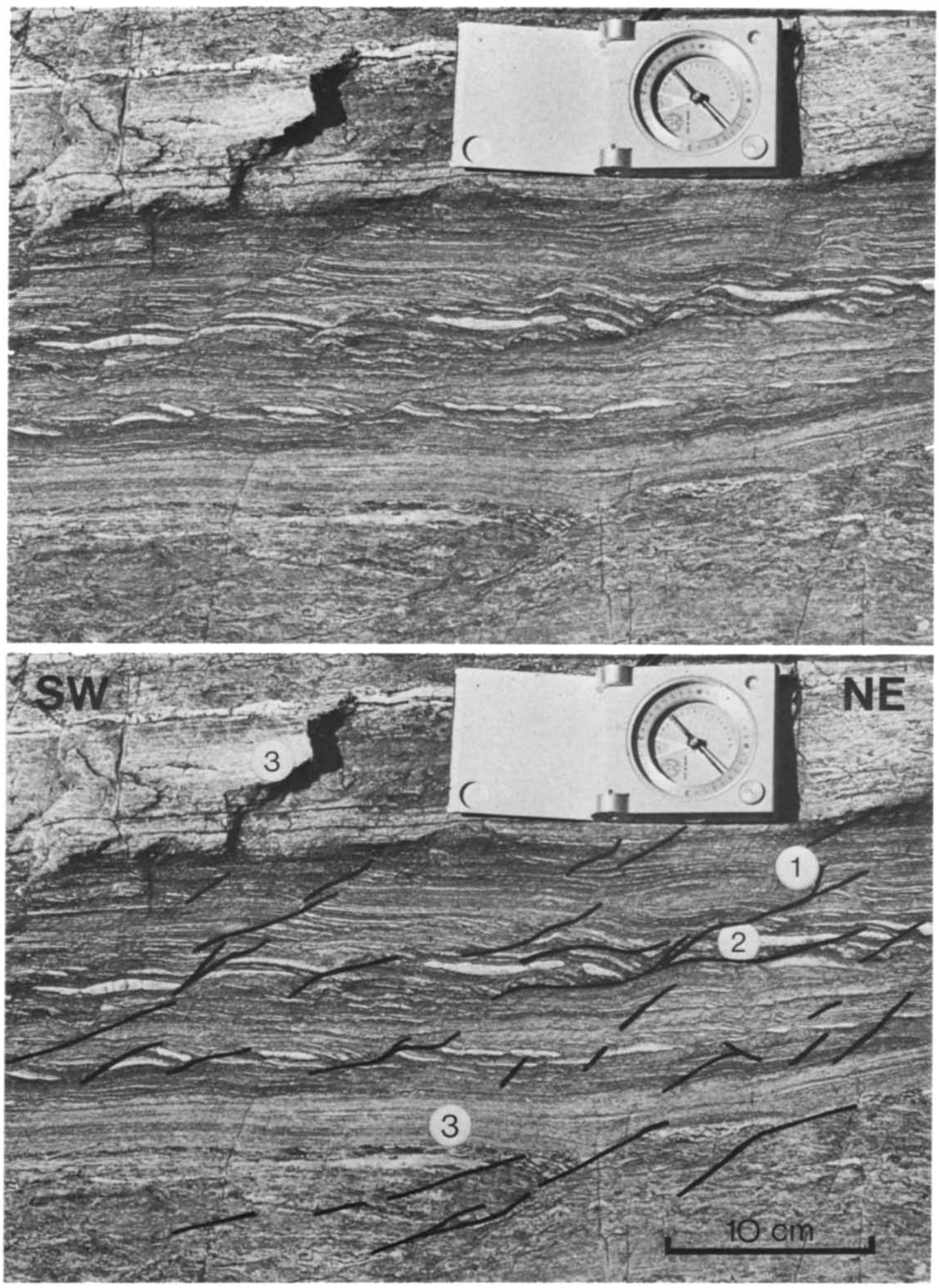

Fig. 2. Extensional crenulation cleavages in mylonitic schists of the Sierra Alhamilla. The lower photograph is a line drawing interpretation of the upper one. Note high angles of propagating eccs with the foliation (1), ramp-flat geometries of evolved eccs (2) and quartzite and quartz schist domains (3) free of secondary cleavages. The regional sense of tectonic movement is top-to-right. 



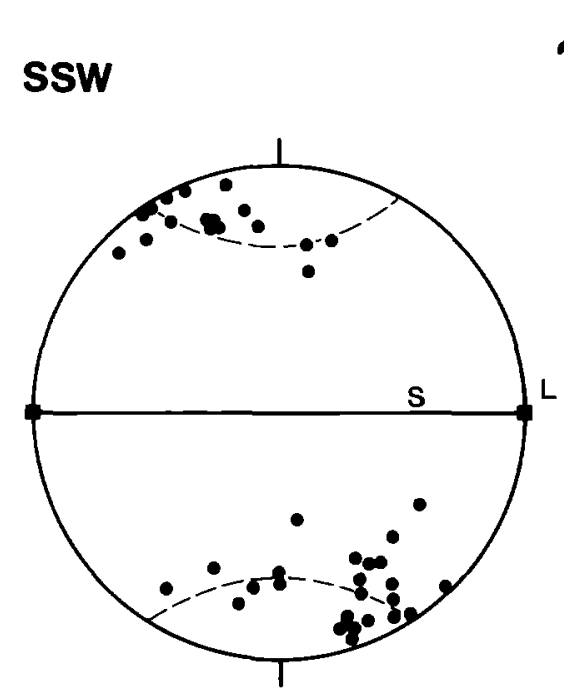

a

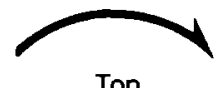

Top
NNE

Fig. 4(a). Orientation of poles to extensional crenulation cleavage planes with respect to the trace of mylonitic foliation $(S)$ and stretching lineation $(L)$. Dashed line, small circle girdle at $30^{\circ}$ to the foliation pole. Data from Platt \& Behrmann (1986). (b) Asymmetric type I crossed girdle of quartz c-axes in a quartzite tectonite from the footwall of the Cuillas mylonite indicating top-to-NNE shear. 150 measurements; contours are 1, 2, 3, 4 and 6 times uniform distribution. (a) and (b) are lower hemisphere, equal-area projections. Curved arrow, sense of vorticity in large-scale flow.

The crossed girdle quartz $c$-axis fabric in Fig. $4(\mathrm{~b})$ is an example of those specimens (see Platt \& Behrmann 1986, fig. 13) that allow an unambiguous interpretation of the sense of vorticity in the regional flow field. The quartz fabric data set depicts variations between coaxial and non-coaxial flow, but is internally consistent with respect to top-to-NNW shearing in the BMZ. The kinematic information from the quartz fabrics also conforms with that of rotated tailed porphyroclasts (deltaclasts in the sense of Jordan 1986, or Passchier \& Simpson 1986) in the Fuentes and Cuillas mylonites (see fig. 6-5 of Behrmann 1982). The ecc orientations from the Cuillas mylonite (Fig. 3) fail to determine a clear-cut sense of vorticity in a structural position where flow must have approximated simple shear ( $\mathrm{km}$-scale displacement in a zone only a few tens of meters wide). In the wall rocks (Fig. 4a) there is only a systematic relationship between ecc and the foliation, but not with the regional sense of vorticity.

\section{SOUTHEASTERN TAUERN WINDOW}

The Tauern Window (Fig. 5) exposes the Penninic nappe complex beneath its tectonic cover comprised of the Austroalpine nappe complex (see e.g. Tollmann 1963). In the southeastern corner of the Tauern Window the base of the Austroalpine complex consists of medium- to high-grade gneisses and mica schists that have undergone intense ductile retrograde shearing (e.g. Exner 1980, Bickle \& Hawkesworth 1978) during their emplacement onto the Pennine. A mylonitic foliation is developed parallel to the contact of the tectonic complexes, and a variably strong stretching lineation trends SE-NW in the Schobergruppe area (Fig. 5) and E-W in the Liesertal area (Fig. 5). Quartz $c$-axis fabrics consis- tently indicate top-to-NW (Fig. 6b) or top-to-W (Fig. 7b) non-coaxial shearing, implying that the Austroalpine sheet was emplaced onto the Pennine sheet from the $E$ to SE. This is compatible with published kinematic data for Alpine deformation within the Pennine (Brunel \& Geyssant 1978) and within the Austroalpine (Ratschbacher 1986) nappe complexes. In the Schobergruppe area extensional crenulation cleavages mostly occur as conjugate sets (Fig. 6a), making average angles of $30^{\circ}$ to the foliation, and intersecting the foliation at approximately $90^{\circ}$ to the stretching lineation. At Liesertal a single set with displacements antithetic to the bulk sense of shear is dominant (Fig. 7a), making angles of somewhat less than $30^{\circ}$ to the foliation, and intersecting the foliation at variable angles to the stretching lineation. The Liesertal example is particularly interesting, as the quartzite fabric (Fig. 7b) and the ecc data (Fig. 7a) come from the same outcrop. Like in the BMZ (Fig. 2), the extensional crenulation cleavages are confined to micarich lithologies, and do not cut across the quartzite layers. The kinematic information from the quartzite fabric is compatible with that from other samples taken from the area, and with the sense of rotation of snowball garnets grown synkinematically with respect to Alpine shearing.

\section{DISCUSSION}

Perhaps the most important question to be asked relevant to the kinematic interpretation of secondary planar fabrics in ductile movement zones is whether large-scale boundary constraints for heterogeneous simple shear (Ramsay \& Graham 1970) have to be relaxed or not for their formation. For ' $C$ '-planes in the sense of Berthé et al. (1979) there is no need for such a relaxation, 


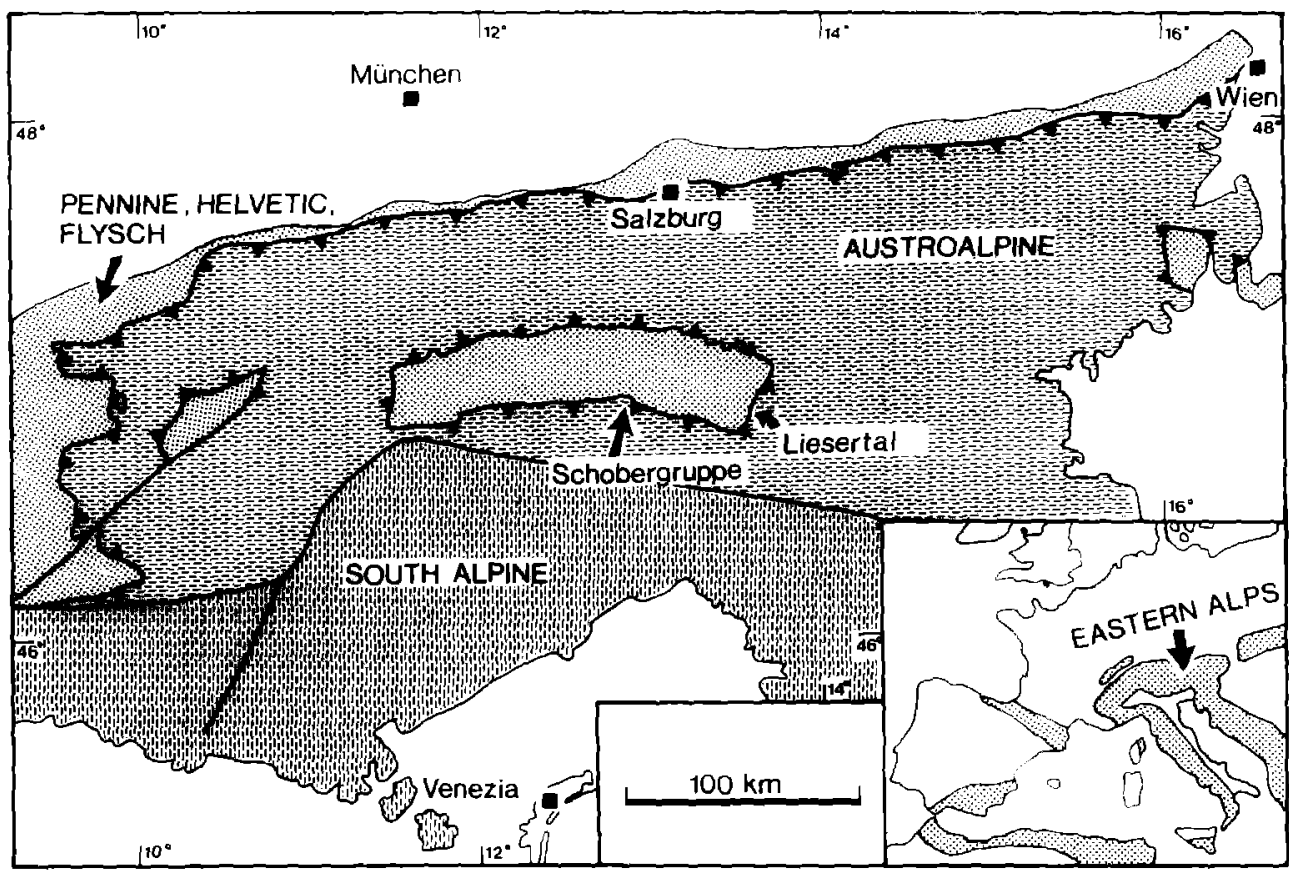

Fig. 5. Tectonic sketch map of the eastern Alps, simplified after Bögel \& Schmidt (1976). Sampling areas for data in Figs. 5 and 6 are shown by arrow tips.

\section{SE}

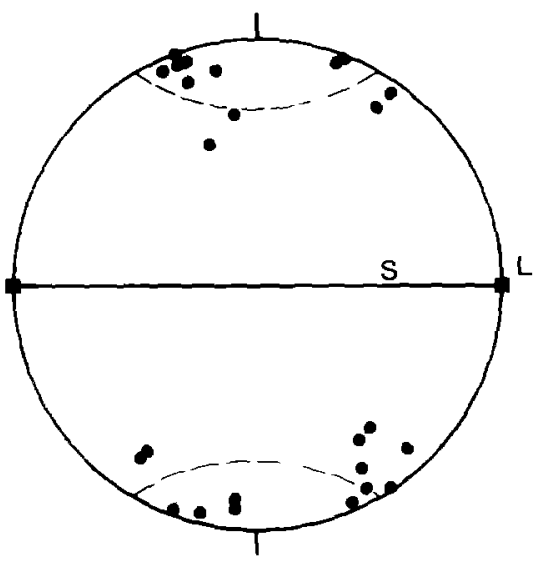

a

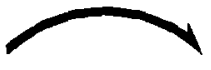

Top

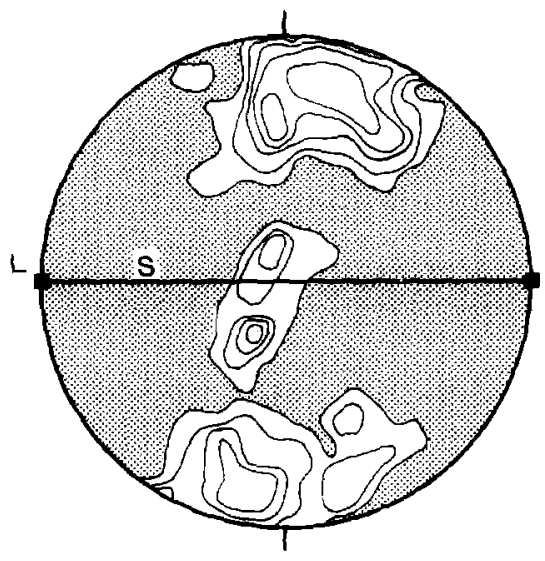

b

Fig. 6(a). Orientations of poles to extensional crenulation cleavage planes, with respect to foliation trace $(S)$ and stretching lineation $(L)$ in the Schobergruppe area. Data have been collected over an area of about $10 \mathrm{~km}^{2}(5 \mathrm{~km}$ east of Kals, Tyrol); each data point is the average of up to five individual measurements per outcrop. Eight locations show conjugate sets of ecc (represented by two data points), two locations show single sets with synthetic displacements, and five locations show single sets with antithetic displacements. (b) Representative $c$-axis fabric of a quartzite tectonite in the Schobergruppe area. The obliquity of the main girdle relative to the foliation trace indicates top-to-NW shearing. 120 measurements; contours are 1, 2, 3, 4 and 6 times uniform distribution. (a) and (b) are equal-area, lower hemisphere projections. Curved arrow, sense of vorticity in large-scale fow 

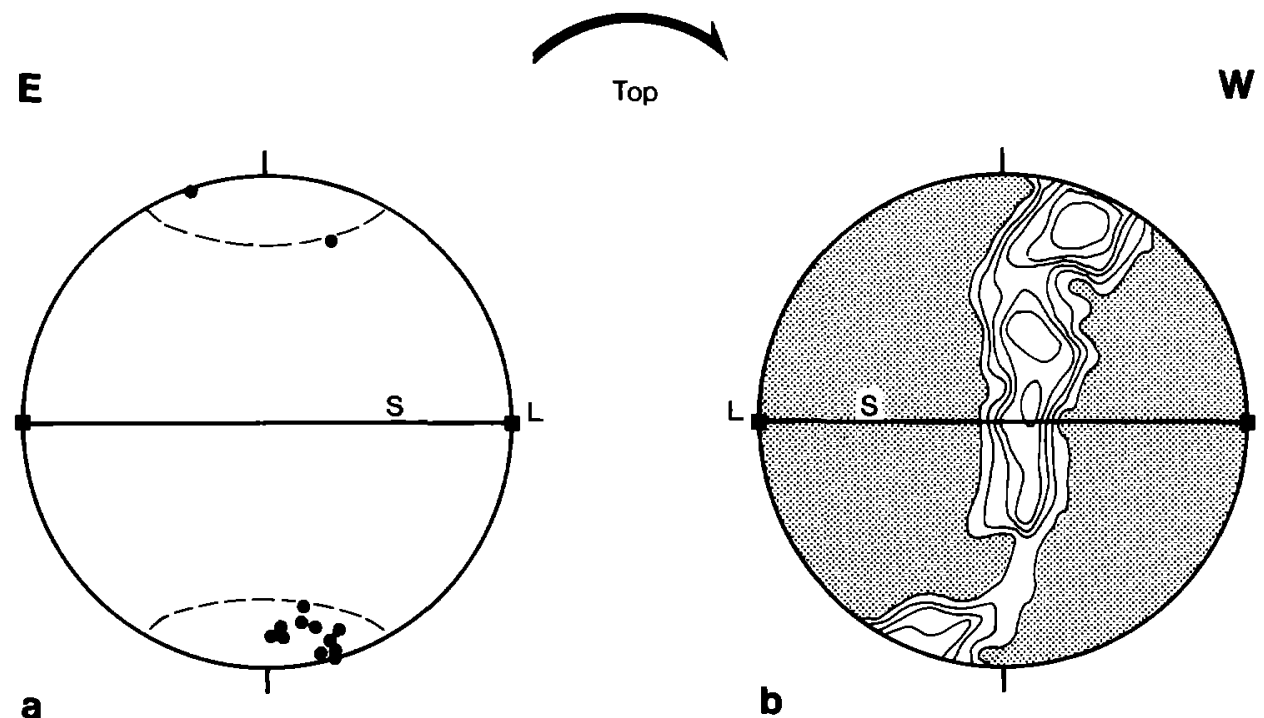

Fig. 7. Data from a road outcrop of retrograde Altkristallin schists at the base of the Austroalpine, Lieserta/Carinthia. The large outcrop is located $1 \mathrm{~km} \mathrm{NE}$ of the village of Trebesing, and is described in Exner (1980, p. 391). (a) Orientations of poles to extensional crenulation cleavage planes relative to foliation trace $(S)$ and stretching lineation $(L)$. (b) Oblique single girdle of $c$-axes in a tectonized quartz vein from the same outcrop. The vein is exactly parallel to the enveloping surface of the mylonitic foliation $(S)$. The obliquity of the girdle indicates top-to-W shearing. 120 measurements; contours are 1,2 , 3, 4, 6 and 10 times uniform distribution. (a) and (b) are lower hemisphere, equal-area projections. Curved arrow, sense of vorticity in large-scale flow.

and the small-scale sense of shear will always match large-scale kinematics. For the generation of any other observed type of secondary cleavage, e.g. for $C^{\prime}$-surfaces of Berthé et al. (1979), shear-bands of White (1979), or extensional crenulation cleavages of Platt (1979) flow needs to be at least locally partitioned (Lister \& Williams 1983) into either simple shear plus spin, or coaxial stretching plus spin components. An instructive discussion of the second case is given in Platt (1984). If simple-shear boundary constraints are not imposed, local deformation may fail to reflect the bulk sense of vorticity and displacement direction. This points out a major-scale problem associated with the use of shear criteria in general. The problem is most severe in strongly anisotropic rocks where deformation is confined to one or two sets of shear bands with orientations governed by mechanical rather than kinematic factors. In comparison, polycrystalline quartz is capable of more homogeneous deformation by multiple intracrystalline slip (e.g. Lister et al. 1978, Mainprice et al. 1986, Schmid \& Casey 1986). Therefore its crystallographic fabrics are likely to be a closer reflection of the kinematic framework. This is manifest in the absence of shear bands, and hence mesoscopic flow partitioning in the quartz-rich lithologies in Fig. 2. Quartz fabrics seem to be good detectors of macroscopic (km-scale) flow partitioning (Behrmann 1982, Law et al. 1984, 1986, Platt \& Behrmann 1986), but appear to give unambiguous information about regional senses of vorticity where flow is non-coaxial.

Conflicting sense of vorticity information from shear bands may hint at large-scale deviations from bulk simple shear within movement zones. This is important in the kinematic interpretation of subhorizontal nappe tec- tonics. Emplacing nappes form the geometrically unconstrained 'lids' of orogenic belts, and contact deformation at their bases or beneath them will only be simple shear at every point if they are perfectly rigid. If they extend in the emplacement direction, as is true for spreading-gliding nappes (e.g. Brun \& Merle 1985, Merle 1986), deformation at their bases may in places deviate significantly from simple shear. Note that all data in this paper come from contact deformation zones at the bases or in the immediate footwall of nappes. However, the descriptions of $C$ fabrics diagnostic for simple shear (Berthé et al. 1979, Ponce de Leon \& Choukroune 1980) come from steep-sided movement zones between presumably rigid crustal blocks. A recently published case study of subhorizontal extensional tectonics (Davis et al. 1986) reports conflicting or indeterminate shear criteria from contact strain zones at the bases of allochthonous units. Here the extending rocks at the hangingwalls of the major detachments provide the same relaxation of kinematic boundary constraints as in nappe tectonics.

\section{CONCLUSION}

Shear band attitudes may be reliable indicators of the regional sense of movement in constant volume shear zones that are bounded by rigid crustal blocks. If based on shear bands alone, the kinematic evaluation of subhorizontal nappe tectonics or crustal extension may be hazardous, and case studies should make use of all other shear criteria available. In general the three-dimensional study of the cases reported reveals a strong mechanical control on shear band generation and orientation. Thus 
the a priori good value of shear bands as kinematic indicators is reduced in movement zones where boundary constraints deviate from bulk simple shear.

Acknowledgements-I thank J. Platt and W. Franke for discussions and comments on an earlier version of the manuscript. Careful reviews by D. Gapais and R. Knipe led to significant improvements, and are gratefully acknowledged.

\section{REFERENCES}

Behrmann, J. H. 1982. Structures and deformational processes in a zone of contact strain beneath a nappe. Sierra Alhamilla, Spain. Unpublished. D.Phil. thesis, University of Oxford.

Behrmann, J. H. 1984a. A study of white mica microstructure and microchemistry in a low grade mylonite. J. Struct. Geol. 6, 283-292.

Behrmann, J. H. 1984b. Patterns of palaeostress and strain beneath the Aguilón nappe, Betic Cordilleras (Spain). Z. dt. Geol Ges. 135 , 293-305.

Behrmann, J. H. \& Plat,, J. P. 1982. Sense of nappe emplacement from quartz- $c$-axis fabrics: an example from the Betic Cordilleras (Spain). Earth Planet. Sci. Lett. 59, 208-215.

Berthé, D., Choukroune, P. \& Gapais, D. 1979. Orientations préférentielles du quartz et orthogneissification progressive en régime cisaillant: l'exemple du cisaillement sud-armoricain. Bull. Minéral. 102, 265-272

Bickle, M. J. \& Hawesworth, C. J. 1978. Deformation phases and the tectonic history of the eastern Alps. Bull. Geol. Soc. Am. 89 , 293-306.

Bögel, H. \& Schmidt, K. 1976. Kleine Geologie der Ostalpen. OttVerlag, Thun.

Brun, J. P. \& Merle, O, 1985. Strain patterns in models of spreadinggliding nappes. Tectonics 4, 705-719.

Brunel, M. \& Geyssant, J. 1978. Mise en évidence d'une déformation rotationelle est-ouest dans la fenêtre des Tauern. Revue Géogr. phys. Géol. dyn. 20, 335-346.

Burg, J. P. \& Harris, L. B. 1982. Tension fractures and boudinage oblique to the maximum extension direction: an analogy with Lüders Bands. Tectonophysics $83,347-363$

Davis, G. A., Lister, G. S. \& Reynolds, S. J. 1986. Structural evolution of the Whipple and South mountains shear zones, southwestern United States. Geology 14, 7-10.

Exner, Ch. 1980. Geologie der Hohen Tauern bei Gmünd in Kärnten. Geol. $J$ b. B. $-A .123,343-410$.

Harris, L. B. \& Cobbold, P. R. 1985. Development of conjugate shear bands during bulk simple shearing. J. Struct. Geol. 7, 37-44.

Hill, R. 1950. The Mathematical Theory of Plasticity. Oxford University Press, Oxford.

Jordan, P. G. 1986. Gefüge-Entwicklung und mechanische Eigenschaften von Zwei-Phasen-Aggregaten (Kalk-Halit) bei experimenteller Deformation. Diss. ETH Zürich.
Law, R. D., Knipe, R. J. \& Dayan, H. 1984. Strain path partitioning within thrust sheets: microstructural and petrofabric evidence from the Moine thrust zone at Loch Eriboli, northwest Scotland. J. Struct. Geol. 6, 477-497.

Law, R. D., Casey, M. \& Knipe, R. J. 1986. Kinematic and tectonic significance of microstructures and crystallographic fabrics within quartz mylonites from the Assynt and Eriboll regions of the Moine thrust zone, NW Scotland. Trans. R. Soc. Edinb. Earth Sci. 77. $99-125$.

Lister, G. S., Paterson, M. S. \& Hobbs, B. E. 1978. The simulation of fabric development in plastic deformation and its application to quartzite: the model. Tectonophysics 45, 107-158.

Lister, G. S. \& Williams, P. F. 1983. The partitioning of deformation in flowing rock masses. Tectonophysics 92, 1-33.

Lister, G. S. \& Snoke, A. W. 1984. S-C mylonites. J. Struct. Cieol. 6, 617-638.

Mainprice, D., Bouchez, J. L., Blumenfeld, P. \& Tubià, J. M. 1986. Dominant $c$ slip in naturally deformed quartz: implications for dramatic plastic softening at high temperature. Geology 14, 819822.

Merle, O. 1986. Patterns of stretch trajectories and strain rates within spreading-gliding nappes. Tectonophysics 124, 211-222.

Passchier, C. W. \& Simpson, C. 1986 Porphyroclast systems as kinematic indicators. J. Struct. Geol. 8, 831-843.

Platt, J. P. 1979. Extensional crenulation cleavage. J. Struct. Geol. I, 95-96

Platt, J. P. 1982. Emplacement of a fold-nappe, Betic Orogen. soulhern Spain. Geology 10, 97-102.

Platt, J. P. 1984. Secondary cleavages in ductile shear zones, J. Struct. Geol. 6, 439-442.

Platt, J. P. \& Behrmann, J. H. 1986. Structures and fabrics in a crustal-scale shear zone, Betic Cordillera, SE Spain. I. Struct. Geol. 8, 15-33.

Platt, J. P. \& Vissers, R. L. M. 1980. Extensional structures in anisotropic rocks. J. Struct. Geol. 2, 387-410.

Ponce de Leon, M. J. \& Choukroune, P. 1980. Shear zones in the Iberian arc. J. Struct. Geol. 2, 63-68.

Ramsay, J. G. \& Graham, R. 1970. Strain variation in shear beits. Can. J. Earth Sci. 7, 786-813.

Ratschbacher, L. 1986. Kinematics of Austro-Alpine cover nappes: changing translation path due to transpression. Tectonophysics 125 , 335-356.

Schmid, S. M. \& Casey, M. 1986. Complete fabric analysis of some commonly observed quartz $c$-axis patterns. In: Mineral and Rock Deformation: Laboratory Studies-the Paterson Volume. AGU Geophys. Monograph 36, 263-286.

Simpson, C. \& Schmid, S M. 1983. An evaluation of criteria to deduce the sense of movement in sheared rocks. Bull. Geol. Soc. Am. 94 1281-1288.

Tollmann, A. 1963. Ostalpensynthese. Deuticke, Wien.

Weijermars, R. \& Rondeel, H. E. 1984. Shear band foliation as indicator of sense of shear: field observations in central Spain. Geology 12, 603-606.

White, S. H. 1979. Large strain deformation: report on a Tectonic Studies Group discussion meeting held at Imperial College. London. J. Struct. Geol. 1, 333-339. 


\section{SHEAR CRITERIA IN ROCKS}

Section IV:

Pressure shadows and porphyroblasts 
